Original paper

\title{
Taurine mitigates bile duct obstruction-associated cholemic nephropathy: effect on oxidative stress and mitochondrial parameters
}

\author{
Narges Abdoli', Issa Sadeghian², Negar Azarpira ${ }^{3}$, Mohammad Mehdi Ommati ${ }^{4}$, Reza Heidari² \\ ${ }^{1}$ Iran Food and Drug Administration, Ministry of Health, Tehran, Iran \\ 2Pharmaceutical Sciences Research Center, Shiraz University of Medical Sciences, Shiraz, Iran \\ ${ }^{3}$ Transplant Research Center, Shiraz University of Medical Sciences, Shiraz, Iran \\ ${ }^{4}$ College of Life Sciences, Shanxi Agricultural University, Taigu, Shanxi 030801, China
}

\begin{abstract}
Aim of the study: Cholestasis is a serious complication affecting other organs such as the liver and kidney. Oxidative stress and mitochondrial impairment are proposed as the primary mechanisms for cholestasis-induced organ injury. Taurine (TAU) is the most abundant free amino acid in the human body, which is not incorporated in the structure of proteins. Several pharmacological effects have been attributed to TAU. It has been reported that TAU effectively mitigated oxidative stress and modulated mitochondrial function. The current study aimed to evaluate the impact of TAU on oxidative stress biomarkers and mitochondrial parameters in the kidney of cholestatic animals.

Material and methods: Bile duct ligated (BDL) rats were used as an antioxidant model of cholestasis. Animals were treated with TAU (500 and $1000 \mathrm{mg} / \mathrm{kg}$, oral) for seven consecutive days. Animals were anesthetized (thiopental $80 \mathrm{mg} / \mathrm{kg}$, i.p.), and kidney and blood specimens were collected.

Results: Severe elevation in serum and urine biomarkers of renal injury was evident in the BDL group. Significant lipid peroxidation, reactive oxygen species (ROS) formation, and protein carbonylation were detected in the kidney of BDL animals. Furthermore, depleted glutathione reservoirs and a significant decrease in the antioxidant capacity of renal tissue were detected in cholestatic rats. Renal tubular atrophy and interstitial inflammation were evident in BDL animals. Cholestasis also caused significant mitochondrial dysfunction in the kidney. TAU significantly prevented cholestasis-induced renal injury by inhibiting oxidative stress and mitochondrial impairment.

Conclusions: These data indicate TAU as a potential therapeutic agent in the management of cholestasis-induced renal injury.
\end{abstract}

Key words: amino acids, bile acids, cirrhosis, cholestasis, nephropathy.

Address for correspondence:

Dr. Reza Heidari, Shiraz University of Medical Sciences, Iran, e-mail: rezaheidari@hotmail.com; rheidari@sums.ac.ir

\section{Introduction}

Taurine (TAU) is the most abundant free amino acid in the human body that does not become incorporated in protein structure. However, several physiological roles, such as osmoregulatory effects, have been attributed to TAU. On the other hand, it has been found that TAU significantly provided a positive impact on different diseases [1-7]. The impact of TAU on cardiovascular diseases, central nervous system (CNS) disorders, and liver damage has been widely investigated [6, 8-16]. It has also been found that TAU also significantly alleviated renal disorders [17].

The effects of TAU on reactive oxygen species (ROS) formation and oxidative stress have been mentioned as a primary mechanism for its cytoprotective properties [12-14, 18-26]. It has been found that TAU significantly mitigated oxidative stress in different experimental 
models [12-14, 18-26]. On the other hand, the effects of TAU on mitochondrial function and mitochondria-associated cell injury mechanisms are among the most exciting mechanisms of cytoprotection provided by this amino acid [12, 26-41]. It has been found that TAU is essential for the proper synthesis of mitochondrial electron chain transport components, preserving mitochondrial membrane matrix $\mathrm{pH}$, preventing mitochondrial depolarization, and decreasing mitochondria-mediated ROS formation [12, 26-41].

Cholemic nephropathy $(\mathrm{CN})$ is a clinical complication associated with cholestasis/cirrhosis. $\mathrm{CN}$ could lead to renal failure or the need for organ transplantation. Although the only promising option is identifying the etiology of $\mathrm{CN}$ and its eradication, preserving renal function and protecting this organ during cholestasis is a critical issue. It has been evident that oxidative stress and mitochondrial impairment play a key role in the pathogenesis of renal injury in $\mathrm{CN}[32$, 42-45]. Therefore, the administration of antioxidants and mitochondria protecting agents could be useful.

In the current study, TAU (500 and $1000 \mathrm{mg} / \mathrm{kg}$, oral) was administered to cholestatic animals. Then, markers of oxidative stress and mitochondrial indices were evaluated. As TAU is a safe amino acid and could be readily administered to patients, the results of this study could help in the development of therapeutic strategies against cholestasis-induced renal injury.

\section{Material and methods}

\section{Reagents}

$\mathrm{N}$-chloro tosylamide (chloramine- $\mathrm{T}$ ), trichloroacetic acid, sodium acetate, citric acid, n-propanol, meta-phosphoric acid, p-dimethyl amino benzaldehyde, 2,4,6-Tri(2-pyridyl)-s-triazine, thiobarbituric acid, sodium citrate, ethylenediamine tetra-acetic acid (EDTA), and 2amino2-hydroxymethyl-propane-1,3-diol-hydrochloride (Tris-HCl) were obtained from Merck (Darmstadt, Germany). Taurine, dichlorodihydrofluorescein diacetate (DFC-DA), and reduced (GSH) and oxidized (GSSG) glutathione were purchased from Sigma-Aldrich (St. Louis, MO, USA). Kits for evaluating biomarkers of organ injury were purchased from Pars Azmun (Tehran, Iran). All salts used for making buffer solutions were of analytical grade and purchased from Merck (Darmstadt, Germany).

\section{Animals}

Male Sprague-Dawley rats ( $n=60,200-250 \mathrm{~g}$ weight) were obtained from Shiraz University of Medical Sci- ences, Shiraz, Iran. Rats were housed in a standard environment (temperature of $23 \pm 1^{\circ} \mathrm{C}$, a 12 light : 12 dark photoschedule, and $40 \%$ relative humidity). Animals had free access to a regular rat's diet (RoyanFeed, Esfahan, Iran) and tap water. All experiments were performed in conformity with the guidelines for care and use of experimental animals and approved by the ethics committee of Shiraz University of Medical Sciences, Shiraz, Iran (\#97-01-36-19359).

\section{Bile duct ligation surgery and experimental setup}

Animals were anesthetized $(10 \mathrm{mg} / \mathrm{kg}$ of xylazine and $70 \mathrm{mg} / \mathrm{kg}$ of ketamine, i.p.). A midline incision was made $(\sim 2 \mathrm{~cm})$, and the common bile duct was localized, doubly ligated, and cut between the ligatures $[46,47]$. The sham operation consisted of laparotomy and bile duct identification and manipulation without ligation. Animals were equally allotted to four groups containing 12 rats in each. Rats were treated as follows: 1) sham-operated (vehicle-treated); 2) bile duct ligated (BDL); 3) BDL + taurine (500 mg/kg, oral); 4) BDL + taurine $(1000 \mathrm{mg} / \mathrm{kg}$, oral) [48]. TAU was administered for seven consecutive days, and its effect on the cholestasis-induced renal injury was assessed $[46,49]$.

\section{Organ weight index}

Animals were weighed, and the organs' (liver, spleen, and kidney) weight indices were measured as organ weight index $=$ [wet organ weight $(\mathrm{g}) /$ body weight $(\mathrm{g})] \times 100$.

\section{Urinalysis and serum biochemistry}

Urine samples were collected during animal handling $(200 \mu \mathrm{l})$ and diluted with $200 \mu \mathrm{l}$ of ice-cooled normal saline $\left(0.9 \% \mathrm{NaCl}, 4^{\circ} \mathrm{C}\right)$. Samples were centrifuged $\left(1000 \mathrm{~g}, 5 \mathrm{~min} 4^{\circ} \mathrm{C}\right)$, and the clear supernatant was used for urinalysis [50]. Then, animals were anesthetized (thiopental $80 \mathrm{mg} / \mathrm{kg}$ ), and blood samples were collected from the abdominal aorta. Samples were centrifuged $\left(3000 \mathrm{~g}, 15 \mathrm{~min} 4^{\circ} \mathrm{C}\right)$, and the separated serum was used. A Mindray auto analyzer and commercial kits (Pars-Azmun, Tehran, Iran) were used to assess biomarkers of organ injury in urine and serum of cholestatic animals [51].

\section{Renal histopathological alterations}

Samples of kidney tissue were fixed in a buffered formalin solution ( $10 \%$ formaldehyde in phosphate buffer, $\mathrm{pH}=7.4$ ). Paraffin-embedded kidney tissue 
(5 $\mu \mathrm{m}$ sections) were prepared and stained with hematoxylin and eosin (H\&E). Kidney and liver fibrotic changes were determined by Masson's trichrome staining in $\mathrm{BDL}$ rats $[52,53]$.

\section{Reactive oxygen species formation}

Reactive oxygen species formation in the kidney was estimated based on a previously described procedure [54-56]. Briefly, $200 \mathrm{mg}$ of the kidney tissue was homogenized in $5 \mathrm{ml}$ of ice-cooled Tris- $\mathrm{HCl}$ buffer $(40 \mathrm{mM}, \mathrm{pH}=7.4)$. Samples of the resultant tissue homogenate $(100 \mu \mathrm{l})$ were mixed with $1 \mathrm{ml}$ of Tris-HCl buffer and 2',7'-dichlorofluorescein diacetate; DCF-DA (final concentration $10 \mu \mathrm{M}$ ). The mixture was incubated at $37^{\circ} \mathrm{C}(15 \mathrm{~min}$, in the dark). Finally, the fluorescence intensity of samples was assessed using a FLUOstar Omega multifunctional fluorimeter $\left(\lambda_{\text {excitation }}=485 \mathrm{~nm}\right.$ and $\left.\lambda_{\text {emission }}=525 \mathrm{~nm}\right)[54,57,58]$.

\section{Lipid peroxidation}

The thiobarbituric acid reactive substances (TBARS) were measured as an index of lipid peroxidation in cholestatic rats' kidney tissue [59-61]. The reaction mixture consisted of $500 \mu \mathrm{l}$ of tissue homogenate $(10 \% \mathrm{w} / \mathrm{v}$ in $\mathrm{KCl}, 1.15 \% \mathrm{w} / \mathrm{v}), 1 \mathrm{ml}$ of thiobarbituric acid $(0.375 \%, \mathrm{w} / \mathrm{v})$, and $3 \mathrm{ml}$ of phosphoric acid $(1 \% \mathrm{w} / \mathrm{v}, \mathrm{pH}=2)$. Samples were mixed well and heated $\left(100^{\circ} \mathrm{C}\right.$ water bath, $\left.45 \mathrm{~min}\right)$. Then, the mixture was cooled to room temperature, and $2 \mathrm{ml}$ of $\mathrm{n}$-butanol was added. Samples were mixed well and centrifuged $(10,000 \mathrm{~g}$ for $10 \mathrm{~min})[55,62]$. Finally, the absorbance of developed color in the n-butanol phase was measured at $532 \mathrm{~nm}$ (EPOCH plate reader, BioTek, USA) $[59,63,64]$.

\section{Renal glutathione content}

The reduced (GSH) and oxidized (GSSG) glutathione levels in the kidney of cholestatic animals were measured using a gradient HPLC method [65]. Briefly, the mobile phases consisted of buffer A (acetate buffer : water; $1: 4 \mathrm{v}: \mathrm{v}$ ) and buffer $B$ (water: methanol; $1: 4 \mathrm{v}: \mathrm{v}$ ). There was a steady increase of buffer $B$ to $95 \%$ in $30 \mathrm{~min}$, and the flow rate was $1 \mathrm{ml} / \mathrm{min}$ was applied [65]. For tissue preparation, the kidney sample (200 mg) was homogenized in Tris-HCl buffer $\left(250 \mathrm{mM}, \mathrm{pH}=7.4,4^{\circ} \mathrm{C}\right)$, and $500 \mu \mathrm{l}$ of TCA $(50 \% \mathrm{w} / \mathrm{v})$ was added to $1 \mathrm{ml}$ of the tissue homogenate. Samples were mixed well and incubated on ice $(10 \mathrm{~min})$. Samples were centrifuged $\left(17,000 \mathrm{~g}, 30 \mathrm{~min}, 4^{\circ} \mathrm{C}\right)$, and the supernatant was collected in $5 \mathrm{ml}$ tubes. Then, $300 \mu \mathrm{l}$ of the $\mathrm{NaOH}: \mathrm{NaHCO}_{3}(2 \mathrm{M}: 2 \mathrm{M})$ was added until the gas production was stopped. Afterward, $100 \mu \mathrm{l}$ of iodoacetic acid $(1.5 \% \mathrm{w} / \mathrm{v}$ in deionized water) was added, and samples were incubated in the dark $\left(1 \mathrm{~h}, 4^{\circ} \mathrm{C}\right)$. After the incubation period, DNFB $(500 \mu \mathrm{l}, 1.5 \% \mathrm{v}$ : $\mathrm{v}$ in ethanol) was added, mixed well, and incubated in the dark $\left(24 \mathrm{~h}, 25^{\circ} \mathrm{C}\right)$. Finally, samples were centrifuged $(17,000 \mathrm{~g}$, $\left.30 \mathrm{~min}, 4^{\circ} \mathrm{C}\right)$ and injected $(50 \mu \mathrm{l})$ into the described HPLC apparatus $[65,66]$. An $\mathrm{NH}_{2}$ column was used as the stationary phase $(25 \mathrm{~cm}$, Bischoff chromatography, Leonberg, Germany) and the UV detector was set at $\lambda=254 \mathrm{~nm}$.

\section{Ferric reducing antioxidant power of kidney tissue}

Ferric reducing antioxidant power (FRAP) assay measures the formation of a blue-colored $\mathrm{Fe}^{2+}$-tripyridyltriazine compound from the colorless oxidized $\mathrm{Fe}^{3+}$ form by the action of electron-donating antioxidants $[67,68]$. In the current study, the working FRAP reagent was freshly prepared by mixing acetate buffer ( 10 volume of $300 \mathrm{mmol} / \mathrm{l}, \mathrm{pH}=3.6)$ with $\mathrm{TPTZ}$ ( 1 volume of $10 \mathrm{mmol} / \mathrm{l}$ in $40 \mathrm{mmol} / \mathrm{l} \mathrm{HCl}$ ) and ferric chloride ( 1 volume of $20 \mathrm{mmol} / \mathrm{l} \mathrm{FeCl} \cdot 6 \mathrm{H}_{2} \mathrm{O}$ ). Kidney tissue $(200 \mathrm{mg}$ ) was homogenized in an ice-cooled Tris- $\mathrm{HCl}$ buffer $\left(250 \mathrm{mM}\right.$ Tris- $\left.\mathrm{HCl}, \mathrm{pH}=7.4,4^{\circ} \mathrm{C}\right)$. Afterward, $100 \mu \mathrm{l}$ of tissue homogenate and $150 \mu \mathrm{l}$ of deionized water were added to $1.5 \mathrm{ml}$ of the FRAP reagent $[69,70]$. The reaction mixture was incubated in the dark $\left(37^{\circ} \mathrm{C}, 5 \mathrm{~min}\right)$. Finally, the absorbance of developed color was measured at $595 \mathrm{~nm}(\mathrm{EPOCH}$ plate reader, BioTek, USA) [55, 71].

\section{Mitochondria isolation from the rat kidney}

The kidney was washed in normal saline $(\mathrm{NaCl}$ $0.9 \% \mathrm{w} / \mathrm{v}, 4^{\circ} \mathrm{C}$ ) and minced in an ice-cold isolation buffer containing $70 \mathrm{mM}$ D-mannitol, $220 \mathrm{mM}$ sucrose, 2 mM HEPES, $0.5 \mathrm{mM}$ EGTA and 0.1\% BSA $(\mathrm{pH}=7.4)$. Minced tissue was transported into mitochondria isolation buffer ( $5 \mathrm{ml}$ buffer : $1 \mathrm{~g}$ tissue) and homogenized. The differential centrifugation method was used to isolate kidney mitochondria $[26,72,73]$. For this purpose, the kidney homogenate was centrifuged $\left(1000 \mathrm{~g}, 20 \mathrm{~min}, 4^{\circ} \mathrm{C}\right)$ to pellet unbroken cells and nuclei. The supernatant was then further centrifuged $\left(10,000 \mathrm{~g}, 20 \mathrm{~min}, 4^{\circ} \mathrm{C}\right)$ to pellet the mitochondria fraction. The second centrifugation step was repeated four times using a fresh mitochondria isolation buffer medium. Finally, isolated kidney mitochondria were re-suspended in a buffer ( $5 \mathrm{ml}$ buffer/ $1 \mathrm{~g}$ tissue) containing $70 \mathrm{mM}$ D-mannitol, $2 \mathrm{mM}$ HEPES, and 
$220 \mathrm{mM}$ sucrose $(\mathrm{pH}=7.4)$. The mitochondria fractions used to assess mitochondrial permeabilization and mitochondrial depolarization were suspended in swelling buffer ( $125 \mathrm{mM}$ sucrose, $65 \mathrm{mM} \mathrm{KCl}, 10 \mathrm{mM}$ HEPES, $\mathrm{pH}=7.2$ ), and mitochondria membrane potential assay buffer $(220 \mathrm{mM}$ sucrose, $10 \mathrm{mM} \mathrm{KCl}$, $68 \mathrm{mM}$ D-mannitol, $5 \mathrm{mM} \mathrm{KH} \mathrm{PO}_{4}, 2 \mathrm{mM} \mathrm{MgCl}$, $50 \mu \mathrm{M}$ EGTA, and $10 \mathrm{mM}$ HEPES, $\mathrm{pH}=7.2)[72,74]$. The protein content of the samples was determined based on the Bradford method.

\section{Mitochondrial ATP levels}

A method based on the luciferase-luciferin reaction (ENLITEN kit from Promega) was used to assess mitochondrial ATP content $[26,75]$. Samples and buffer solutions were made based on the kit instructions, and the luminescence intensity of samples was measured $(\lambda=560 \mathrm{~nm}$ using a FLUOstar Omega fluorimeter) [76].

\section{Mitochondrial depolarization assay}

Mitochondrial uptake of rhodamine 123 was used to assess mitochondrial depolarization [77-79]. Briefly, kidney isolated mitochondria $(0.5 \mathrm{mg}$ protein $/ \mathrm{ml}$; in the depolarization assay buffer) were incubated with rhodamine $123\left(30 \mathrm{~min}, 37^{\circ} \mathrm{C}\right.$, in the dark). Afterward, samples were centrifuged $\left(17,000 \mathrm{~g}, 5 \mathrm{~min}, 4^{\circ} \mathrm{C}\right)$, and the fluorescence intensity of the supernatant was monitored with a fluorimeter (FLUOstar Omega, Germany; $\lambda_{\text {excitation }}=485 \mathrm{~nm}$ and $\left.\lambda_{\text {emission }}=525 \mathrm{~nm}\right)[77,80]$.

\section{Lipid peroxidation in kidney mitochondria}

Thiobarbituric acid-reactive substances (TBARS) were assessed in kidney mitochondria isolated from cholestatic animals. Previous studies mentioned that sucrose interrupts the lipid peroxidation test in isolated mitochondria [81]. Therefore, sucrose was removed by washing mitochondria preparation in ice-cooled MOPS-KCl buffer (50 mM MOPS, $10 \mu \mathrm{M}$ Trolox, and $100 \mathrm{mM} \mathrm{KCl}, 4^{\circ} \mathrm{C}, \mathrm{pH}=7.4$ ). For this purpose, $1 \mathrm{ml}$ of isolated kidney mitochondria $(1 \mathrm{mg}$ protein $/ \mathrm{ml})$ was suspended in $5 \mathrm{ml}$ of MOPS- $\mathrm{KCl}$ buffer and centrifuged $(15,000 \mathrm{~g}, 20 \mathrm{~min})$. The pellet was re-suspended in $1 \mathrm{mM}$ of MOPS- $\mathrm{KCl}$ buffer and used for TBARS assay [82, 83]. For this purpose, the mitochondrial suspension $(1 \mathrm{mg}$ protein $/ \mathrm{ml}$ ) was mixed with $1 \mathrm{ml}$ of TBARS assay reagent containing trichloroacetic acid $(15 \% \mathrm{w} / \mathrm{v}), \mathrm{HCl}(240 \mathrm{mM})$, thiobarbituric acid $(0.375 \% \mathrm{w} / \mathrm{v})$, and $10 \mu \mathrm{l}$ of Trolox $(500 \mu \mathrm{M})$. Samples were heated for $15 \mathrm{~min}$ at $100^{\circ} \mathrm{C}$ [81]. Afterward, samples were centrifuged $\left(17,000 \mathrm{~g}, 20 \mathrm{~min}, 4^{\circ} \mathrm{C}\right)$, and the absorbance was measured at $\lambda=532 \mathrm{~nm}(\mathrm{EPOCH}$ plate reader, BioTek Instruments, USA) [81].

\section{Statistical methods}

Data are given as mean \pm SD. A comparison of data sets was performed by one-way analysis of variance (ANOVA) with Tukey's multiple comparisons as the post hoc test. Values of $p<0.05$ were considered statistically significant.

\section{Results}

A significant increase in serum biomarkers of organ injury [alanine transaminase (ALT), aspartate transaminase (AST), and lactate dehydrogenase (LDH), alkaline phosphatase (ALP), $\gamma$-glutamyltransferase ( $\gamma$-GT), bile acids, and bilirubin) was detected in the BDL model of cholestasis. On the other hand, serum

Table 1. Serum biochemical measurements in cirrhotic rats

\begin{tabular}{|c|c|c|c|c|}
\hline Parameters assessed & Sham-operated & BDL & $\begin{array}{c}\text { BDL } \\
+ \text { TAU } 500 \mathrm{mg} / \mathrm{kg}\end{array}$ & $\begin{array}{c}\text { BDL } \\
+ \text { TAU } 1000 \mathrm{mg} / \mathrm{kg}\end{array}$ \\
\hline $\operatorname{ALT}(\mathrm{U} / \mathrm{I})$ & $53 \pm 16$ & $232 \pm 90$ & $118 \pm 37^{a}$ & $108 \pm 25^{a}$ \\
\hline AST (U/I) & $107 \pm 17$ & $207 \pm 38^{*}$ & $128 \pm 27$ & $118 \pm 13^{a}$ \\
\hline $\mathrm{LDH}(\mathrm{U} / \mathrm{l})$ & $493 \pm 169$ & $1580 \pm 432^{*}$ & $1105 \pm 292$ & $950 \pm 76^{a}$ \\
\hline $\operatorname{ALP}(U / I)$ & $1265 \pm 332$ & $2676 \pm 652^{*}$ & $2781 \pm 569$ & $1893 \pm 133^{a}$ \\
\hline$\gamma$-GT $(\mathrm{U} / \mathrm{I})$ & $27 \pm 6$ & $242 \pm 82^{*}$ & $178 \pm 84$ & $204 \pm 77$ \\
\hline Total bilirubin (mg/dl) & $0.1 \pm 0.07$ & $11.9 \pm 1.30^{*}$ & $9.89 \pm 1.88$ & $11 \pm 1.72$ \\
\hline Albumin (mg/dl) & $3.96 \pm 0.14$ & $3.22 \pm 0.36^{*}$ & $3.5 \pm 0.20$ & $3.94 \pm 0.54^{\mathrm{a}}$ \\
\hline BUN (mg/dl) & $30 \pm 12$ & $41 \pm 9$ & $42 \pm 11$ & $36 \pm 11$ \\
\hline Creatinine (mg/dl) & $0.22 \pm 0.04$ & $0.69 \pm 0.17^{*}$ & $0.3 \pm 0.08^{a}$ & $0.28 \pm 0.11^{\mathrm{a}}$ \\
\hline
\end{tabular}

Data are given as mean $\pm S D(n=8)$. The effect of taurine (TAU) on serum biomarkers of organ injury was not dose-dependent in the current study.

*Indicates significantly different as compared with the sham group $(p<0.001)$.

a Indicates significantly different as compared with the BDL group $(p<0.05)$. 
creatinine as a renal injury marker was significantly higher in BDL rats. No significant BUN changes were detected seven days after the BDL operation in the current study. It was found that TAU (500 and $1000 \mathrm{mg} / \mathrm{kg}$, seven consecutive days) mitigated serum markers of hepatic and renal injury (Table 1). Hepatomegaly and splenomegaly were also evident in BDL rats, which confirm the occurrence of cholestasis. No significant kidney weight index changes were detected seven days after the BDL surgery. TAU (500 and $1000 \mathrm{mg} / \mathrm{kg}$, oral) significantly decreased hepatomegaly and splenomegaly in BDL rats (Fig. 1). The effect of TAU on serum biomarkers of organ injury (Table 1), as well as liver and spleen weight indices (Fig. 1), was not dose-dependent in the current study.

Urinalysis revealed a significant increase in glucose, ALP, $\gamma$-GT, bile acids, and bilirubin in cholestatic rats. It was found that TAU treatment significantly alleviated urine markers of renal injury in BDL rats. The effects of TAU on urine biomarkers were not dose-dependent in the current model (Fig. 2).

Decreased mitochondrial dehydrogenase activity, mitochondrial depolarization, decreased ATP stores, lipid peroxidation, and mitochondrial permeabilization were evident in the kidney mitochondria isolated from cholestatic animals. TAU (500 and $1000 \mathrm{mg} / \mathrm{kg}$, oral) significantly improved mitochondrial indices in BDL rats. The effect of TAU on renal mitochondrial indices was not dose-dependent in cholestatic rats (Fig. 3).

Tubular atrophy and interstitial inflammation were the most prominent renal histopathological alterations even days after the BDL surgery (Fig. 4 and Table 3). On the other hand, it was found that TAU treatment significantly ameliorated cholestasis-induced renal injury in BDL animals (Fig. 4 and Table 3). The effects of TAU on renal histopathological alterations were not dose-dependent (Fig. 4 and Table 2).

\section{Discussion}

Cholestasis-induced renal injury (also known as cholemic nephropathy, $\mathrm{CN}$ ) is a severe clinical complication that could lead to renal failure or the need for organ transplantation. Although the only promising option is identifying the etiology of $\mathrm{CN}$ and its eradication (e.g., gall stones), preserving renal function and protecting this organ during cholestasis is a critical issue. In the current study, we found that administration of TAU (500 and $1000 \mathrm{mg} / \mathrm{kg}$, oral, seven consecutive days) to cholestatic animals could significantly preserve renal function and prevent cholestasis-induced renal injury. The effects of TAU on oxidative stress markers and mitochondrial indices seem to be the fundamental mechanisms for this amino acid's nephroprotective effects in the current model.

Oxidative stress and its associated events such as lipid peroxidation, protein carbonylation, and defect in enzymatic and non-enzymatic antioxidant systems have been mentioned as key mechanisms involved in the pathogenesis of $\mathrm{CN}$ [42-45]. Several studies have mentioned the positive effects of antioxidants against cholestasis [84-86]. N-acetyl cysteine, proline, $\alpha$-lipoic acid, betaine, selenium, glycine, boldine, agmatine, and several other agents have been used to ameliorate cholestasis-induced organ injury [42, 62, 73, 87-92].

It has repeatedly been mentioned that TAU could alleviate oxidative stress status in various experimental models [12-14, 18-26]. The effects of TAU on enzymatic and non-enzymatic antioxidant systems have been noted as a cytoprotective mechanism for this amino acid $[12-14,18-26]$. On the other hand, it has been
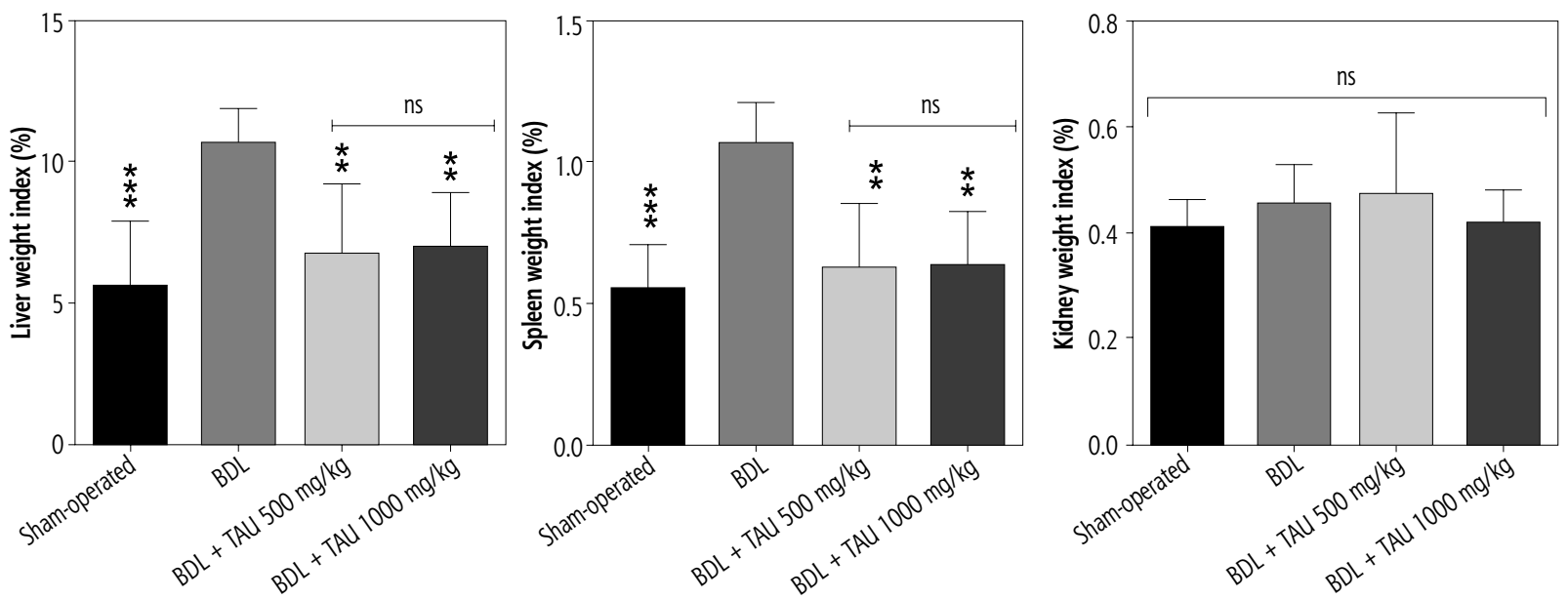

Fig. 1. Organ weight index in cirrhotic rats. Data are given as mean $\pm \mathrm{SD}(n=8) .{ }^{*}$ Indicates significantly different as compared with the $\mathrm{BDL}$ group $(p<0.01)$ 

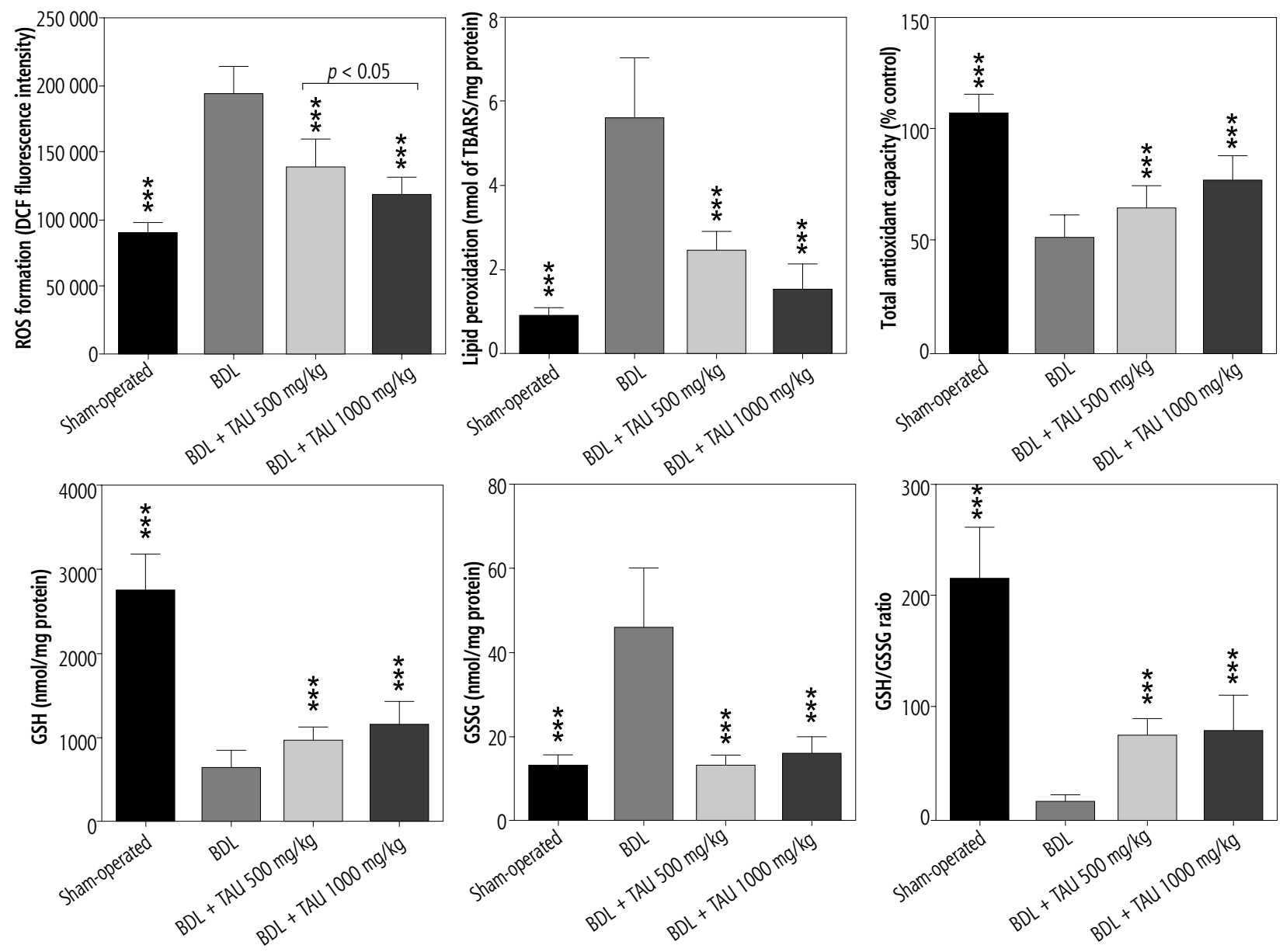

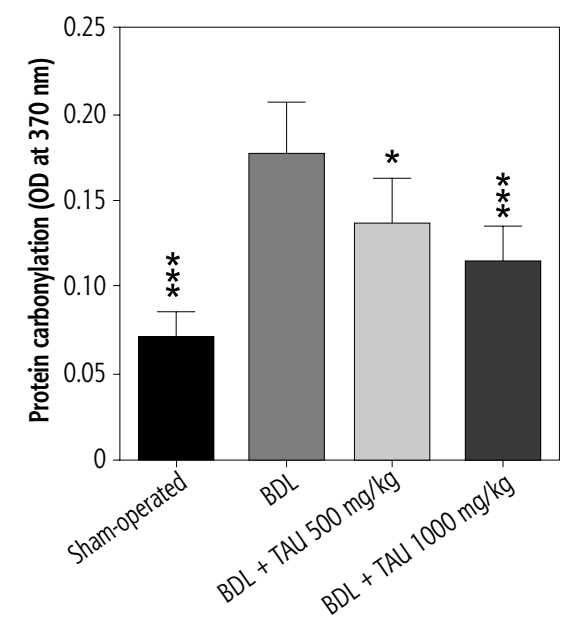

found that TAU is not an excellent radical scavenger. Hence several studies mention other mechanisms for the cytoprotection provided by this amino acid.

The effect of TAU on cellular mitochondria is a new and exciting mechanism of action provided by this amino acid [12, 26-41]. Recent studies mentioned that the most crucial antioxidant mechanism of TAU is mediated through its effects on cellular mitochondria $[12,26-41,93]$. It has been found that TAU effectively mitigated mitochondria-mediated ROS formation
[26, 29, 35, 94-96]. TAU also regulates the synthesis of mitochondria electron transport chain components and enhances mitochondrial ATP [26, 29, 35, 94-97]. Our data are in agreement with investigations indicating the occurrence of oxidative stress in the kidney of cholestatic animals. On the other hand, we found that mitochondrial impairment in renal tissue of cholestatic rats could act as a significant source of ROS and oxidative stress in this disease. We found that TAU mitigated oxidative stress in the renal tissue of cholestatic 

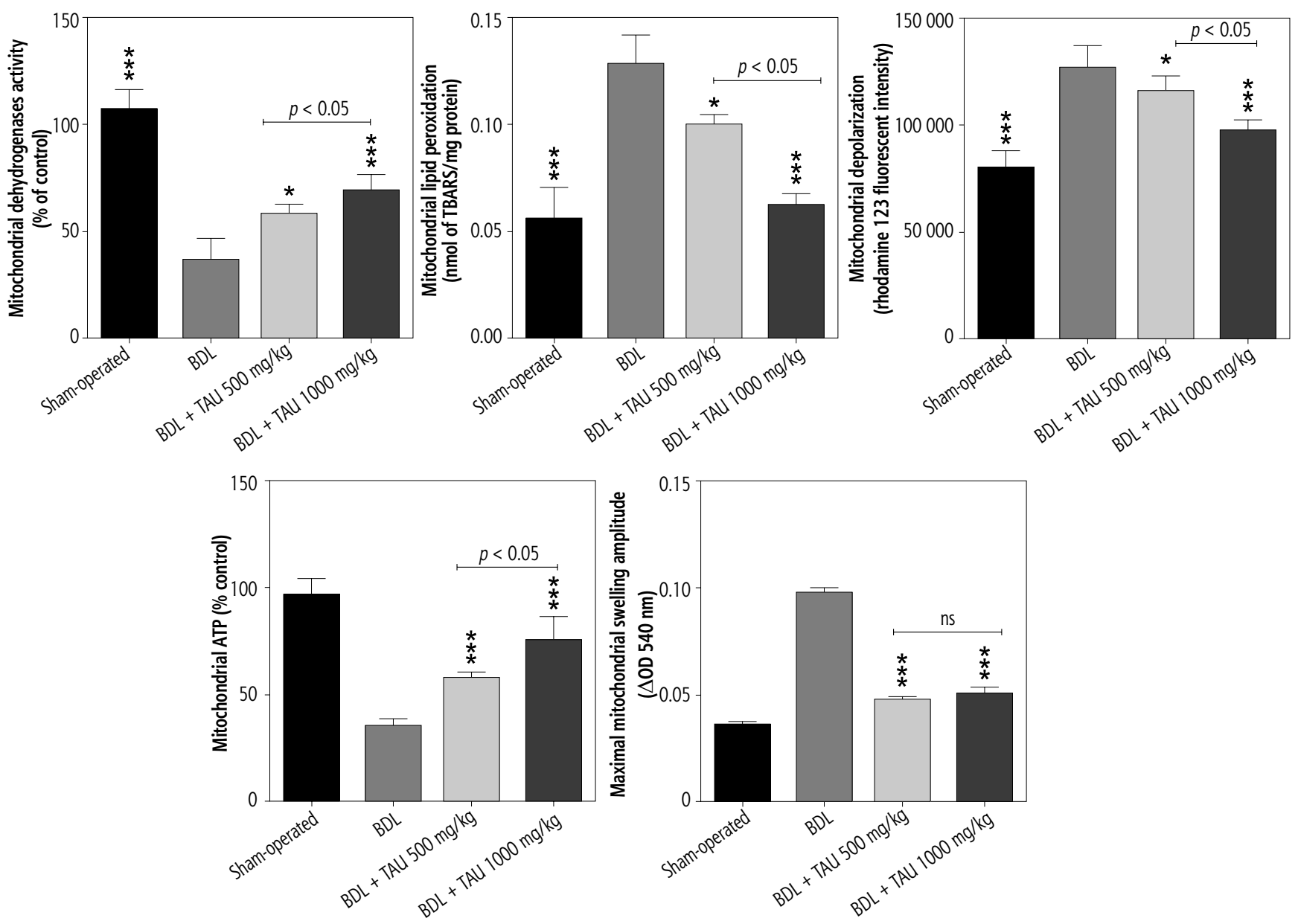

Fig. 3. Mitochondrial indices in the kidney of cholestatic animals. TAU - taurine, TBARS - thiobarbituric acid reactive substances. Data are given as mean \pm SD $(n=8)$. Asterisks indicate significantly different as compared with the BDL group $\left({ }^{*} p<0.05\right.$ and $\left.{ }^{* * *} p<0.001\right)$
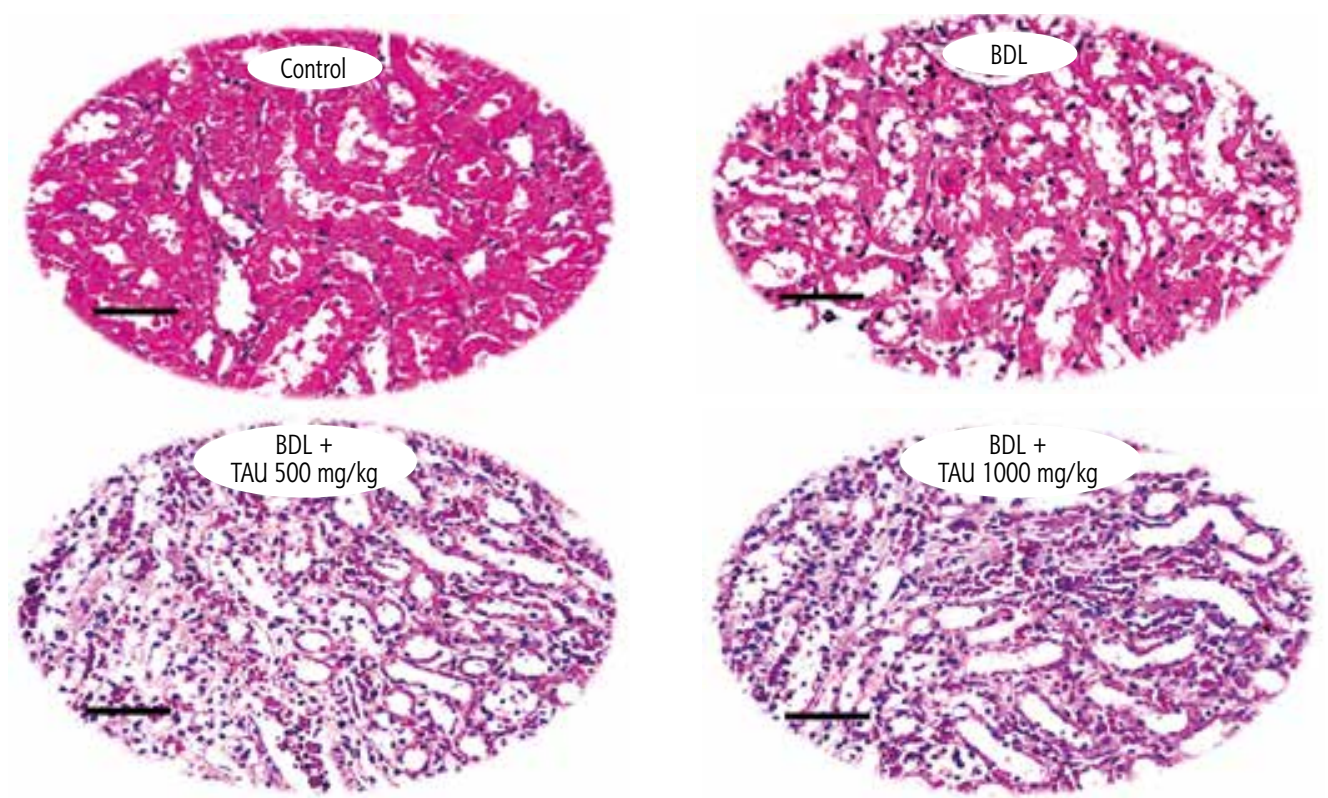

Fig. 4. Taurine (TAU) treatment mitigates renal histopathological changes in cholestatic rats. BDL - bile duct ligated. H\&E staining (scale bar $100 \mu \mathrm{m}$ ). Tubular atrophy and interstitial inflammation were the prominent histopathological alterations in the BDL animals (7 days after BDL surgery) (Table 3). It was found that taurine (500 and $1000 \mathrm{mg} / \mathrm{kg}$, oral) mitigated renal histopathological changes in BDL rats (Table 3) 
Table 2. Urinalysis of bile duct ligated (BDL) rats treated with taurine (TAU)

\begin{tabular}{|c|c|c|c|c|}
\hline Parameters assessed & Sham-operated & BDL & $\begin{array}{c}\text { BDL } \\
+ \text { TAU } 500 \mathrm{mg} / \mathrm{kg}\end{array}$ & $\begin{array}{c}\text { BDL } \\
+ \text { TAU } 1000 \mathrm{mg} / \mathrm{kg}\end{array}$ \\
\hline Glucose (mg/dl) & $67 \pm 9$ & $141 \pm 14^{*}$ & $112 \pm 6^{a}$ & $109 \pm 11^{a}$ \\
\hline $\operatorname{ALP}(\mathrm{U} / \mathrm{I})$ & $1450 \pm 248$ & $4333 \pm 564^{*}$ & $30100 \pm 559^{a}$ & $2792 \pm 343^{a}$ \\
\hline$\gamma$-GT $(\mathrm{U} / \mathrm{l})$ & $2142 \pm 392$ & $4361 \pm 810^{*}$ & $2822 \pm 305^{a}$ & $2541 \pm 300^{\mathrm{a}}$ \\
\hline Total bilirubin (mg/dl) & $0.49 \pm 0.13$ & $4.8 \pm 1^{*}$ & $4.77 \pm 1$ & $3.4 \pm 1.5$ \\
\hline Bile acids (mg/dl) & $3.9 \pm 1.1$ & $55.3 \pm 11^{*}$ & $64 \pm 15$ & $72 \pm 11$ \\
\hline
\end{tabular}

Data are given as mean $\pm S D(n=8)$.

*Indicates significantly different as compared with the sham group $(p<0.001)$.

andicates significantly different as compared with the BDL group $(p<0.05)$.

Table 3. Renal tissue histopathological alterations in bile duct ligated (BDL) rats seven days after BDL surgery

\begin{tabular}{lcc}
\hline Group & Tubular atrophy & $\begin{array}{c}\text { Interstitial } \\
\text { inflammation }\end{array}$ \\
\hline Sham-operated & - & - \\
\hline $\mathrm{BDL}$ & +++ & ++ \\
\hline $\mathrm{BDL}+$ TAU $500 \mathrm{mg} / \mathrm{kg}$ & + & + \\
\hline $\mathrm{BDL}+$ TAU $1000 \mathrm{mg} / \mathrm{kg}$ & + & - \\
\hline,+++++ , and + indicate severe, moderate, and mild histopathological alterations. \\
TAU - taurine
\end{tabular}

animals. The antioxidative mechanism of TAU in this study might be mediated through its effects on renal mitochondrial function.

TAU is a safe compound [98]. On the other hand, this amino acid is under clinical trials for the management of several diseases [99]. Previous studies mentioned the positive effects of TAU on cholestasis/cirrhosis [14, 78, 84, 86, 99-105]. Therefore, TAU might be readily administered in cholestatic patients to prevent renal injury. Finally, our results suggest the potential protective effects of taurine on cirrhosis-associated renal injury. Nevertheless, the precise impact of TAU on the renal function in cholestasis and the clinical relevance of these data require further studies for clarification.

\section{Acknowledgments}

This investigation was financially supported by the Vice-Chancellor of Research Affairs of Shiraz University of Medical Sciences (Grant number: 19359/14883). The authors thank the Pharmaceutical Sciences Research Center of Shiraz University of Medical Sciences for providing technical facilities to carry out this study. The Shanxi Government Scholarship also supported this study for International Research Assistant (National Natural Science Foundation of China (CN);
Grant No. 2018YJ33; provided by Dr. M. Mehdi Ommati), and outstanding doctors volunteering to work in Shanxi Province (No. K271999031; by Dr. M. Mehdi Ommati), Shanxi province, China.

\section{Disclosure}

The authors declare no conflict of interest.

\section{References}

1. Timbrell JA, Seabra V, Waterfield CJ. The in vivo and in vitro protective properties of taurine. General Pharmacol 1995; 26 : 453-462.

2. Saransaari P, Oja SS. Taurine and neural cell damage. Amino Acids 2000; 19: 509-526.

3. Schaffer S, Azuma J, Takahashi K, Mozaffari M. Why is taurine cytoprotective? Taurine 2000; 5: 307-312.

4. Menzie J, Pan C, Prentice H, Wu JY. Taurine and central nervous system disorders. Amino Acids 2012; 46: 31-46.

5. Miyazaki T, Matsuzaki Y. Taurine and liver diseases: a focus on the heterogeneous protective properties of taurine. Amino Acids 2012; 46: 101-110.

6. Kumari N, Prentice H, Wu JY. Taurine and its neuroprotective role. Adv Exp Med Biol 2013; 775: 19-27.

7. Marcinkiewicz J, Kontny E. Taurine and inflammatory diseases. Amino Acids 2014; 46: 7-20.

8. Heidari R, Sadeghi N, Azarpira N, Niknahad H. Sulfasalazine-induced hepatic injury in an ex vivo model of isolated perfused rat liver and the protective role of taurine. Pharm Sci 2015; 21: 211-219.

9. Karamikhah R, Jamshidzadeh A, Azarpira N, et al. Propylthiouracil-induced liver injury in mice and the protective role of taurine. Pharm Sci 2015; 21: 94-101.

10. Heidari R, Jamshidzadeh A, Niknahad H, et al. The hepatoprotection provided by taurine and glycine against antineoplastic drugs induced liver injury in an ex vivo model of normothermic recirculating isolated perfused rat liver. Trend Pharm Sci 2016; 2: 59-76.

11. Jamshidzadeh A, Abdoli N, Niknahad H, et al. Taurine alleviates brain tissue markers of oxidative stress in a rat model of hepatic encephalopathy. Trend Pharm Sci 2017; 3: 181-192.

12. Jamshidzadeh A, Heidari R, Abasvali M, et al. Taurine treatment preserves brain and liver mitochondrial function in a rat mod- 
el of fulminant hepatic failure and hyperammonemia. Biomed Pharmacother 2017; 86: 514-520.

13. Niknahad H, Jamshidzadeh A, Heidari R, et al. Ammoniainduced mitochondrial dysfunction and energy metabolism disturbances in isolated brain and liver mitochondria, and the effect of taurine administration: relevance to hepatic encephalopathy treatment. Clin Exp Hepatol 2017; 3: 141-151.

14. Heidari R, Jamshidzadeh A, Ghanbarinejad V, et al. Taurine supplementation abates cirrhosis-associated locomotor dysfunction. Clin Exp Hepatol 2018; 4: 72-82.

15. Heidari R, Ghanbarinejad V, Mohammadi H, et al. Dithiothreitol supplementation mitigates hepatic and renal injury in bile duct ligated mice: Potential application in the treatment of cholestasis-associated complications. Biomed Pharmacother 2018; 99: 1022-1032.

16. Zulli A. Taurine in cardiovascular disease. Curr Opin Clin Nutr Metab Care 2011; 14: 57.

17. Chesney RW, Han X, Patters AB. Taurine and the renal system. J Biomed Sci 2010; 17: S4.

18. Devamanoharan PS, Ali AH, Varma SD. Oxidative stress to rat lens in vitro: protection by taurine. Free Radic Res 1998; 29: 189-195.

19. Gürer H, Ozgünes H, Saygin E, Ercal N. Antioxidant effect of taurine against lead-induced oxidative stress. Arch Environ Contam Toxicol 2001; 41: 397-402.

20. Obrosova IG, Fathallah L, Stevens MJ. Taurine counteracts oxidative stress and nerve growth factor deficit in early experimental diabetic neuropathy. Exp Neurol 2001; 172: 211-219.

21. Boşgelmez İI, Söylemezoğlu T, Güvendik G. The protective and antidotal effects of taurine on hexavalent chromium-induced oxidative stress in mice liver tissue. Biol Trace Elem Res 2008; 125: 46-58

22. Schaffer SW, Azuma J, Mozaffari M. Role of antioxidant activity of taurine in diabetes. Can J Physiol Pharmacol 2009; 87: 91-99.

23. Han Z, Gao LY, Lin YH, et al. Neuroprotection of taurine against reactive oxygen species is associated with inhibiting NADPH oxidases. Eur J Pharmacol 2016; 777: 129-135.

24. Jong CJ, Ito T, Prentice $\mathrm{H}$, et al. Role of mitochondria and endoplasmic reticulum in taurine-deficiency-mediated apoptosis. Nutrients 2017; 9: 795.

25. Scicchitano BM, Sica G. The beneficial effects of taurine to counteract sarcopenia. Curr Protein Peptide Sci 2018; 19: 673-680.

26. Ommati MM, Heidari R, Ghanbarinejad V, et al. Taurine treatment provides neuroprotection in a mouse model of manganism. Biol Trace Elem Res 2019; 190: 384-395.

27. Heidari R, Babaei H, Eghbal MA. Ameliorative effects of taurine against methimazole-induced cytotoxicity in isolated rat hepatocytes. Sci Pharm 2012; 80: 987-1000.

28. Heidari R, Babaei H, Eghbal MA. Cytoprotective effects of taurine against toxicity induced by isoniazid and hydrazine in isolated rat hepatocytes. Arh Hig Rada Toksikol 2013; 64: 15-24.

29. Heidari R, Babaei H, Eghbal MA. Amodiaquine-induced toxicity in isolated rat hepatocytes and the cytoprotective effects of taurine and/or N-acetyl cysteine. Res Pharm Sci 2014; 9: $97-$ 105.

30. Heidari R, Abdoli N, Ommati MM, et al. Mitochondrial impairment induced by chenodeoxycholic acid: The protective effect of taurine and carnosine supplementation. Trend Pharm Sci 2018; 4.

31. Heidari R, Ghanbarinejad V, Ommati MM, et al. Mitochondria protecting amino acids: Application against a wide range of mitochondria-linked complications. PharmaNutrition 2018; 6: 180-190.
32. Heidari R. The footprints of mitochondrial impairment and cellular energy crisis in the pathogenesis of xenobiotics-induced nephrotoxicity, serum electrolytes imbalance, and Fanconi's syndrome: A comprehensive review. Toxicology 2019; 423: 1-31.

33. El Idrissi A, Trenkner E. Taurine regulates mitochondrial calcium homeostasis. Taurine 2003; 5: 527-536.

34. Schaffer S, Azuma J, Takahashi K, Mozaffari M. Why is taurine cytoprotective? Adv Exp Med Biol 2003; 526: 307-321.

35. Hansen SH, Andersen ML, Birkedal H, et al. The important role of taurine in oxidative metabolism. Adv Exp Med Biol 2006; 583: 129-135.

36. Hansen SH, Andersen ML, Cornett C, et al. A role for taurine in mitochondrial function. J Biomed Sci 2010; 17: 1-8.

37. Jong CJ, Azuma J, Schaffer S. Mechanism underlying the antioxidant activity of taurine: prevention of mitochondrial oxidant production. Amino Acids 2012; 42: 2223-2232.

38. Hansen SH, Grunnet N. Taurine, glutathione and bioenergetics. Adv Exp Med Biol 2013; 776: 3-12.

39. Schaffer SW, Jong CJ, Ito T, Azuma J. Effect of taurine on ischemia-reperfusion injury. Amino Acids 2014; 46: 21-30.

40. Hansen SH, Birkedal H, Wibrand F, Grunnet N. Taurine and regulation of mitochondrial metabolism. Adv Exp Med Biol 2015; 803: 397-405.

41. Schaffer S, Kim HW. Effects and mechanisms of taurine as a therapeutic agent. Biomol Ther (Seoul) 2018; 26: 225-241.

42. Ahmadi N, Ghanbarinejad V, Ommati MM, et al. Taurine prevents mitochondrial membrane permeabilization and swelling upon interaction with manganese: Implication in the treatment of cirrhosis-associated central nervous system complications. J Biochem Mol Toxicol 2018; 32: e22216.

43. Heidari R, Mandegani L, Ghanbarinejad V, et al. Mitochondrial dysfunction as a mechanism involved in the pathogenesis of cirrhosis-associated cholemic nephropathy. Biomed Pharmacother 2019; 109: 271-280.

44. Heidari R, Niknahad H. The role and study of mitochondrial impairment and oxidative stress in cholestasis. Methods Mol Biol 2019; 1981: 117-132.

45. Abdoli N, Sadeghian I, Mousavi K, et al. Suppression of cirrhosis-related renal injury by $\mathrm{N}$-acetyl cysteine. Curr Res Pharmacol Drug Discov 2020; 1: 30-38.

46. Moezi L, Heidari R, Amirghofran Z, et al. Enhanced anti-ulcer effect of pioglitazone on gastric ulcers in cirrhotic rats: The role of nitric oxide and IL-1b. Pharmacol Rep 2013; 65: 134-143.

47. Ommati MM, Farshad O, Niknahad H, et al. Oral administration of thiol-reducing agents mitigates gut barrier disintegrity and bacterial lipopolysaccharide translocation in a rat model of biliary obstruction. Curr Res Pharmacol Drug Discov 2020; 1: 10-18.

48. Karamikhah R, Jamshidzadeh A, Azarpira N, et al. Propylthiouracil-induced liver injury in mice and the protective role of taurine. Pharm Sci 2016; 21: 94-101.

49. Moezi L, Janahmadi Z, Amirghofran Z, et al. The increased gastroprotective effect of pioglitazone in cholestatic rats: role of nitric oxide and tumour necrosis factor alpha. Int J Exp Pathol 2014; 95: 78-85.

50. Emadi E, Abdoli N, Ghanbarinejad V, et al. The potential role of mitochondrial impairment in the pathogenesis of imatinibinduced renal injury. Heliyon 2019; 5: e01996.

51. Heidari R, Babaei H, Eghbal MA. Amodiaquine-induced toxicity in isolated rat hepatocytes and the cytoprotective effects of taurine and/or N-acetyl cysteine. Res Pharm Sci 2014; 9: 97105 
52. Goodman ZD. Grading and staging systems for inflammation and fibrosis in chronic liver diseases. J Hepatol 2007; 47: 598607.

53. Brunt EM. Grading and staging the histopathological lesions of chronic hepatitis: the Knodell histology activity index and beyond. Hepatology 2000; 31: 241-246.

54. Gupta R, Dubey DK, Kannan GM, Flora SJS. Concomitant administration of Moringa oleifera seed powder in the remediation of arsenic-induced oxidative stress in mouse. Cell Biol Int 2007; 31: 44-56.

55. Heidari R, Jamshidzadeh A, Niknahad $\mathrm{H}$, et al. Effect of taurine on chronic and acute liver injury: Focus on blood and brain ammonia. Toxicol Report 2016; 3: 870-879.

56. Ommati MM, Shi X, Li H, et al. The mechanisms of arsenic-induced ovotoxicity, ultrastructural alterations, and autophagic related paths: An enduring developmental study in folliculogenesis of mice. Ecotoxicol Environ Saf 2020; 204: 110973.

57. Socci DJ, Bjugstad KB, Jones HC, et al. Evidence that oxidative stress is associated with the pathophysiology of inherited hydrocephalus in the H-Tx rat model. Exp Neurol 1999; 155: 109-117.

58. Ommati MM, Jamshidzadeh A, Niknahad H, et al. N-acetylcysteine treatment blunts liver failure-associated impairment of locomotor activity. PharmaNutrition 2017; 5: 141-147.

59. Heidari R, Babaei H, Roshangar L, Eghbal MA. Effects of enzyme induction and/or glutathione depletion on methimazole-induced hepatotoxicity in mice and the protective role of N-acetylcysteine. Adv Pharm Bull 2014; 4: 21-28.

60. Siavashpour A, Khalvati B, Azarpira N, et al. Poly (ADP-Ribose) polymerase-1 (PARP-1) overactivity plays a pathogenic role in bile acids-induced nephrotoxicity in cholestatic rats. Toxicol Lett 2020; 330: 144-158.

61. Ommati MM, Heidari R, Jamshidzadeh A, et al. Dual effects of sulfasalazine on rat sperm characteristics, spermatogenesis, and steroidogenesis in two experimental models. Toxicol Lett 2018; 284: 46-55.

62. Heidari R, Niknahad H, Sadeghi A, et al. Betaine treatment protects liver through regulating mitochondrial function and counteracting oxidative stress in acute and chronic animal models of hepatic injury. Biomed Pharmacother 2018; 103: 75-86.

63. Jamshidzadeh A, Heidari R, Latifpour Z, et al. Carnosine ameliorates liver fibrosis and hyperammonemia in cirrhotic rats. Clin Res Hepatol Gastroenterol 2017; 41: 424-434.

64. Ahmadian E, Khosroushahi AY, Eftekhari A, et al. Novel angiotensin receptor blocker, azilsartan induces oxidative stress and NFkB-mediated apoptosis in hepatocellular carcinoma cell line HepG2. Biomed Pharmacother 2018; 99: 939-946.

65. Meeks RG, Harrison S. Hepatotoxicology. CRC Press, New York 1991.

66. Truong DH, Eghbal MA, Hindmarsh W, et al. Molecular mechanisms of hydrogen sulfide toxicity. Drug Metab Rev 2006; 38 : 733-744.

67. Katalinic V, Modun D, Music I, Boban M. Gender differences in antioxidant capacity of rat tissues determined by 2,2 '-azinobis (3-ethylbenzothiazoline 6-sulfonate; ABTS) and ferric reducing antioxidant power (FRAP) assays. Comparat Biochem Physiol 2005; 140: 47-52.

68. Ommati MM, Manthari RK, Tikka C, et al. Arsenic-induced autophagic alterations and mitochondrial impairments in HPG-S axis of mature male mice offspring (F1-generation): A persistent toxicity study. Toxicol Lett 2020; 326: 83-98.

69. Heidari R, Jafari F, Khodaei F, et al. Mechanism of valproic acid-induced Fanconi syndrome involves mitochondrial dysfunc- tion and oxidative stress in rat kidney. Nephrology 2018; 23: 351-361.

70. Ommati MM, Heidari R, Manthari RK, et al. Paternal exposure to arsenic resulted in oxidative stress, autophagy, and mitochondrial impairments in the HPG axis of pubertal male offspring. Chemosphere 2019; 236: 124325.

71. Alía M, Horcajo C, Bravo L, Goya L. Effect of grape antioxidant dietary fiber on the total antioxidant capacity and the activity of liver antioxidant enzymes in rats. Nutr Res 2003; 23: 1251-1267.

72. Fernández-Vizarra E, Ferrín G, Pérez-Martos A, et al. Isolation of mitochondria for biogenetical studies: An update. Mitochondrion 2010; 10: 253-262.

73. Ommati MM, Farshad O, Ghanbarinejad V, et al. The nephroprotective role of carnosine against ifosfamide-induced renal injury and electrolytes imbalance is mediated via the regulation of mitochondrial function and alleviation of oxidative stress. Drug Res 2020; 70: 49-56.

74. Jamshidzadeh A, Niknahad H, Heidari R, et al. Carnosine protects brain mitochondria under hyperammonemic conditions: Relevance to hepatic encephalopathy treatment. PharmaNutrition 2017; 5: 58-63.

75. Held P. Luminescent determination of ATP concentrations using the Clarity ${ }^{\mathrm{mix}}$ luminescence microplate reader. Nat Methods 2006.

76. Bradford MM. A rapid and sensitive method for the quantitation of microgram quantities of protein utilizing the principle of protein-dye binding. Anal Biochem 1976; 72: 248-254.

77. Ahmadian E, Babaei H, Mohajjel Nayebi A, et al. Mechanistic approach for toxic effects of bupropion in primary rat hepatocytes. Drug Res 2017; 67: 217-222.

78. Heidari R, Ahmadi A, Mohammadi H, et al. Mitochondrial dysfunction and oxidative stress are involved in the mechanism of methotrexate-induced renal injury and electrolytes imbalance. Biomed Pharmacother 2018; 107: 834-840.

79. Ommati MM, Farshad O, Mousavi K, et al. Betaine supplementation mitigates intestinal damage and decreases serum bacterial endotoxin in cirrhotic rats. PharmaNutrition 2020; 12: 100179.

80. Ahmadian E, Eftekhari A, Fard JK, et al. In vitro and in vivo evaluation of the mechanisms of citalopram-induced hepatotoxicity. Arch Pharm Res 2017; 40: 1296-1313.

81. Caro AA, Adlong LW, Crocker SJ, et al. Effect of garlic-derived organosulfur compounds on mitochondrial function and integrity in isolated mouse liver mitochondria. Toxicol Lett 2012; 214: $166-174$.

82. Farshad O, Ommati MM, Len J, et al. Skeletal muscle mitochondrial impairment in cirrhosis-induced sarcopenia. Trend Pharm Sci 2020; 6: 189-204.

83. Heidari R, Jafari F, Khodaei F, et al. Mechanism of valproic acid-induced Fanconi syndrome involves mitochondrial dysfunction and oxidative stress in rat kidney. Nephrology 2018; 23 : 351-361.

84. Guertin F, Roy CC, Lepage G, et al. Effect of taurine on total parenteral nutrition-associated cholestasis. J Parent Ent Nutr 1991; 15: 247-251.

85. Nakashima T, Shima T, Sakamoto Y, et al. Effects of bile acids and taurine on the lipid fluidity of hepatic microsomes in normal and bile duct-ligated rats - a spin label study. J Hepatol 1993; 18: 74-79.

86. Kerai MD, Waterfield CJ, Kenyon SH, et al. Taurine: protective properties against ethanol-induced hepatic steatosis and lipid peroxidation during chronic ethanol consumption in rats. Amino Acids 1998; 15: 53-76. 
87. Ommati MM, Amjadinia A, Mousavi K, et al. $\mathrm{N}$-acetyl cysteine treatment mitigates biomarkers of oxidative stress in different tissues of bile duct ligated rats. Stress 2020; 1-16.

88. Mohammadi H, Sayad A, Mohammadi M, et al. N-acetyl cysteine treatment preserves mitochondrial indices of functionality in the brain of hyperammonemic mice. Clin Exp Hepatol 2020; 6: 106-115.

89. Atalay E, Ozdemir MT, Tur BK, et al. The effect of alpha-lipoic acid on oxidative parameters and liver injury in rats with obstructive jaundice. Bratisl Lek Listy 2019; 120: 843-848.

90. Heidari R, Mohammadi H, Ghanbarinejad V, et al. Proline supplementation mitigates the early stage of liver injury in bile duct ligated rats. J Basic Clin Physiol Pharmacol 2018; 30: 91-101.

91. Heidari R, Moezi L, Asadi B, et al. Hepatoprotective effect of boldine in a bile duct ligated rat model of cholestasis/cirrhosis. PharmaNutrition 2017; 5: 109-117.

92. Ommati MM, Farshad O, Azarpira N, et al. Betaine alleviates cholestasis-associated renal injury by mitigating oxidative stress and enhancing mitochondrial function. Biologia 2020.

93. Ommati MM, Farshad O, Jamshidzadeh A, Heidari R. Taurine enhances skeletal muscle mitochondrial function in a rat model of resistance training. PharmaNutrition 2019; 9: 100161.

94. Li S, Guan H, Qian Z, et al. Taurine inhibits 2,5-hexanedione-induced oxidative stress and mitochondria-dependent apoptosis in PC12 cells. Ind Health 2017; 55: 108-118.

95. Schuller-Levis GB, Park E. Taurine: new implications for an old amino acid. FEMS Microbiol Lett 2003; 226: 195-202.

96. Hansen SH, Andersen ML, Cornett C, et al. A role for taurine in mitochondrial function. J Biomed Sci 2010; 17: S23.

97. Mohammadi H, Ommati MM, Farshad O, et al. Taurine and isolated mitochondria: A concentration-response study. Trend Pharm Sci 2019; 5: 197-206.

98. Shao A, Hathcock JN. Risk assessment for the amino acids taurine, l-glutamine and l-arginine. Regul Toxicol Pharmacol 2008; 50: 376-399.

99. Vidot H, Cvejic E, Carey S, et al. Randomised clinical trial: oral taurine supplementation versus placebo reduces muscle cramps in patients with chronic liver disease. Aliment Pharmacol Ther 2018; 48: 704-712.

100. Lu K, Zimmermann M, Görg B, et al. Hepatic encephalopathy is linked to alterations of autophagic flux in astrocytes. EBioMedicine 2019; 48: 539-553.

101. Balkan J, Dogğru-Abbasoğlul S, Kanbaglil Ö, et al. Taurine has a protective effect against thioacetamide-induced liver cirrhosis by decreasing oxidative stress. Hum Exp Toxicol 2001; 20: 251-254.

102. Liang J, Deng X, Lin ZX, et al. Attenuation of portal hypertension by natural taurine in rats with liver cirrhosis. World J Gastroenterol 2009; 15: 4529-4537.

103. Fang YJ, Chiu CH, Chang YY, et al. Taurine ameliorates alcoholic steatohepatitis via enhancing self-antioxidant capacity and alcohol metabolism. Food Res Int 2011; 44: 3105-3110.

104. Abdel-Moneim AM, Al-Kahtani MA, El-Kersh MA, Al-Omair MA. Free radical-scavenging, anti-inflammatory/anti-fibrotic and hepatoprotective actions of taurine and silymarin against CCl4 induced rat liver damage. PLoS One 2015; 10: e0144509.

105. Schwarzer R, Kivaranovic D, Mandorfer M, et al. Randomised clinical study: the effects of oral taurine $6 \mathrm{~g} /$ day vs placebo on portal hypertension. Aliment Pharmacol Ther 2018; 47: 86-94. 